\title{
Strawberry Nursery Soil Fumigation and Runner Plant Production
}

\author{
Kirk D. Larson ${ }^{1}$ and Douglas V. Shaw ${ }^{2}$ \\ Department of Pomology, University of California, Davis, CA 95616
}

Additional index words. chloropicrin, Fragaria $\times$ ananassa, growth, methyl bromide, runner plants, stolons, trichloronitromethane

\begin{abstract}
Three preplant soil fumigation treatments were applied on 5 Apr. 1993 to a nursery site that had not been planted previously to strawberries (Fragaria $\times$ ananassa

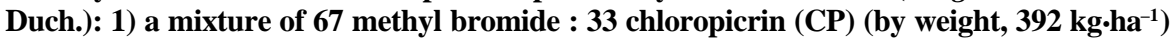
(MBCP); 2) $140 \mathrm{~kg} \mathrm{CP/ha;} \mathrm{and} \mathrm{3)} \mathrm{nonfumigation} \mathrm{(NF).} \mathrm{On} 26$ Apr., cold-stored 'Chandler' and 'Selva' strawberry plants of registered stock were established in each treatment. Soil and root/crown disease symptoms were absent in all treatments during the course of the study. In October, runner plants were machine-harvested and graded to commercial standards. The cultivars produced a similar number of runners per mother plant. Fumigation with MBCP, CP, and NF resulted in 18.56, 15.75, and 7.89 runners per mother plant, respectively. For 'Selva', runner root and crown dry weights were similar for the $\mathrm{MBCP}$ and $\mathrm{CP}$ treatments, but NF resulted in significant reductions compared to the other two treatments. For 'Chandler', fumigation with $\mathrm{CP}$ resulted in reduced root dry weight, and NF resulted in reduced crown and root dry weights compared to fumigation with MBCP. The results demonstrate the marked decreases in strawberry runner production and runner size that can occur in the absence of preplant soil fumigation, even on new strawberry ground. Also, small, but significant, reductions in runner production and runner size may occur with $\mathrm{CP}$ applied at a rate of $140 \mathrm{~kg} \cdot \mathrm{ha}^{-1}$ compared to standard fumigation with MBCP. Chemical name used: trichloronitromethane (chloropicrin).
\end{abstract}

In California, $\approx 11,000$ ha of strawberries produced a crop valued at about $\$ 450,000,000$ in 1993 (California Processing Strawberry Advisory Board, 1993). As in other highyielding strawberry production systems, California strawberries are grown in annual hill culture, which requires the production of $\approx 500,000,000$ runner (stolon) plants in nurseries each year. About $90 \%$ of the California strawberry hectarage is planted to material grown in high-elevation (>1000 m elevation) nurseries (Voth and Bringhurst, 1990; Welch, 1989).

Strawberry nurseries in California use preplant soil fumigation with mixtures of methyl bromide and chloropicrin $(\mathrm{CP})$ to enhance production of disease- and nematode-free runner plants and to control weeds. Preplant soil fumigation results in increased strawberry plant vigor and productivity, which have been attributed to two sources: 1) reduced plant mortality due to control or elimination of lethal pathogens, and 2) increased plant vigor due to the reduction or elimination of a highly variable complex of sublethal or competitive soil

Received for publication 19 Sept. 1994. Accepted for publication 12 Dec. 1994. We gratefully acknowledge the cooperation of Lassen Canyon Nursery, Redding, Calif., and Tri-Cal, Hollister, Calif., in conducting this study. The cost of publishing this paper was defrayed in part by the payment of page charges. Under postal regulations, this paper therefore must be hereby marked advertisement solely to indicate this fact.

${ }^{1}$ Assistant Pomologist, Univ. of California, South Coast Research and Extension Center, 7601 Irvine Blvd., Irvine, CA 92718.

${ }^{2}$ Associate Professor. microorganisms (Wilhelm and Paulus, 1980). Although numerous studies have demonstrated the benefits of preplant soil fumigation for strawberry productivity (Himelrick and Dozier, 1991; Wilhelm et al., 1974; Wilhelm and Paulus, 1980; Yuen et al., 1991), most of these studies concerned performance of strawberry plants in fruiting fields, rather than runner production in nurseries.

Methyl bromide has been classified as an ozone-depleting compound (Watson et al., 1992), and the U.S. Environmental Protection Agency (EPA) requires a phase out of its production and use by the year 2001. In view of the EPA ruling, alternative technologies are needed to ensure the continued production of disease- and nematode-free plant material for strawberry, as well as other horticultural crops. Soil fumigation with CP controls many soilborne fungal pathogens that are major limitations to growth and productivity in California strawberry nurseries and fruit production fields (Wilhelm, 1961); in addition, CP has some herbicidal activity (unpublished data, K.D. Larson et al., 1993). CP is registered for strawberry as a preplant soil fumigant and, therefore, is a possible alternative to soil fumigation with mixtures of methyl bromide and $\mathrm{CP}$.

\section{Materials and Methods}

We conducted a study in a high-elevation strawberry nursery near Macdoel, Calif., (lat. $41.8^{\circ} \mathrm{N}$, elevation $1300 \mathrm{~m}$ ) to determine the influence of three preplant soil fumigation treatments, applied in the spring, on runner production: 1) a mixture of 67 methyl bromide : $33 \mathrm{CP}$ (by weight, $392 \mathrm{~kg} \cdot \mathrm{ha}^{-1}$ ) (MBCP); 2) $140 \mathrm{~kg} \mathrm{CP} / \mathrm{ha}$; and 3 ) nonfumigation (NF).
Treatments were applied on 5 Apr. 1993 by a commercial applicator. There were three replications per treatment, with each one measuring $3.35 \times 30.5 \mathrm{~m}$. The site had never been planted to strawberries; previous crops included sugar beets (Beta vulgaris L.), alfalfa (Medicago sativa L.), grain, and potatoes (Solanum tuberosum L.).

On 26 Apr., cold-stored 'Chandler' and 'Selva' mother plants were established in separate plots, each $3.35 \times 3.66 \mathrm{~m}$, in all treatments. There was concern that soil fumigation would result in greater runner plant population densities, resulting in reduced runner plant size compared to nonfumigation. Therefore, for each treatment and cultivar, mother plants were established using two plant spacings: the typical in-row plant spacing used for each cultivar in that nursery $(30 \mathrm{~cm}$ for 'Selva', 36 $\mathrm{cm}$ for 'Chandler') and a wider in-row spacing that was $1.5 \times$ normal. The intention was to harvest plots from all three fumigation treatments that had similar runner plant densities, thereby avoiding runner size differences due to differences in plant density. There were two plots for each cultivar in each treatment/replicate, one plot for each spacing. Thus, the experiment design was a randomized complete block for treatment and cultivar, with mother plant spacing nested in treatment and cultivar. Fumigation treatments were replicated three times, for a total of 36 plots (three fumigation treatments, two cultivars, two spacings, three replications). Mother plants were established in double rows $91 \mathrm{~cm}$ apart. Following planting, normal nursery practices were employed through the growing season.

Adverse weather conditions during plantation establishment resulted in about a $15 \%$ mortality of mother plants, regardless of soil treatment. Symptoms of plant disease were absent in all treatments, and there was no effect of fumigation treatment on plant mortality during the remainder of the study. Thus, the main effect of fumigation in this study appeared to be the result of competition from sublethal soil organisms, rather than specific, lethal pathogens.

Entire plots of 'Chandler' and 'Selva' were machine-harvested on 8 and 17 Oct. 1993, respectively. All plants were graded to commercial standards, after which the number of marketable runners produced per plot and per mother plant was determined. For each cultivar and each spacing in each treatment replicate, 15 runners were randomly selected for determining crown and root dry weights $(96 \mathrm{~h}$ at 60C). Due to differences in nursery digging dates, and hence differences in runner size for the two cultivars, dry weights were determined separately for each cultivar.

\section{Results and Discussion}

There was a highly significant effect $(P \leq$ $0.01)$ of soil fumigation on runner production (Table 1). Although there was a significant effect $(P \leq 0.05)$ of mother plant spacing on the number of runners produced per plot, there were no effects of spacing or cultivar on the number of runners produced per mother plant 
Table 1. Results for analysis of variance for strawberry runner production with two cultivars and two mother plant spacings in each of three soil fumigation treatments.

\begin{tabular}{|c|c|c|c|c|c|}
\hline \multirow[b]{2}{*}{ Source } & \multirow[b]{2}{*}{ df } & \multicolumn{4}{|c|}{ Mean squares } \\
\hline & & $\begin{array}{c}\text { Runners/ } \\
\text { plot }\end{array}$ & $\begin{array}{c}\text { Runners/ } \\
\text { mother plant }\end{array}$ & $\begin{array}{c}\text { Root } \\
\text { dry wt }\end{array}$ & $\begin{array}{l}\text { Crown } \\
\text { dry wt }\end{array}$ \\
\hline Between subjects & 35 & & & & \\
\hline Replication & 2 & 2710.75 & 10.85 & 0.47 & 0.046 \\
\hline Fumigation (F) & 2 & $111578.58^{* *}$ & $367.10^{* * *}$ & $7.09^{* *}$ & $0.383^{* *}$ \\
\hline Cultivar (C) & 1 & 6889.00 & 5.07 & $19.92^{* *}$ & $0.829^{* *}$ \\
\hline Error (a) & 10 & 2396.72 & 7.82 & 0.33 & 0.031 \\
\hline Spacing $(\mathrm{S})$ & 1 & $9344.44^{*}$ & 13.00 & 1.05 & 0.006 \\
\hline $\mathrm{F} \times \mathrm{S}$ & 2 & 291.69 & 2.97 & 0.44 & 0.001 \\
\hline $\mathrm{C} \times \mathrm{S}$ & 1 & 136.11 & 1.34 & 0.05 & 0.033 \\
\hline $\mathrm{F} \times \mathrm{C} \times \mathrm{S}$ & 2 & 963.86 & 2.14 & 0.30 & 0.030 \\
\hline Error (b) & 14 & 1754.93 & 5.92 & 0.45 & 0.025 \\
\hline
\end{tabular}

${ }^{*, * *}$ Significant at $P \leq 0.05$ or 0.01 , respectively.

Table 2. Soil fumigation treatment and mean runner production and mean crown and root dry weights for 'Selva' and 'Chandler' strawberry plants.

\begin{tabular}{|c|c|c|c|c|c|}
\hline \multirow[b]{3}{*}{ Fumigant $^{\mathrm{y}}$} & \multirow[b]{3}{*}{$\begin{array}{c}\text { Runners/ } \\
\text { mother } \\
\text { plant }^{\mathrm{x}}\end{array}$} & \multicolumn{4}{|c|}{ Cultivar } \\
\hline & & \multicolumn{2}{|c|}{ Selva } & \multicolumn{2}{|c|}{ Chandler } \\
\hline & & $\begin{array}{l}\text { Crown } \\
\text { dry } w t^{z} \\
(\mathrm{~g})\end{array}$ & $\begin{array}{l}\text { Root } \\
\text { dry wt } \\
(\mathrm{g})\end{array}$ & $\begin{array}{l}\text { Crown } \\
\text { dry wt } \\
\text { (g) }\end{array}$ & $\begin{array}{l}\text { Root } \\
\text { dry wt } \\
(\mathrm{g})\end{array}$ \\
\hline$\overline{\mathrm{MBCP}}$ & $18.6 \mathrm{a}^{\mathrm{w}}(0.77)$ & $1.71 \mathrm{a}(0.07)$ & $4.31 \mathrm{a}(0.31)$ & $1.42 \mathrm{a}(0.06)$ & $2.66 \mathrm{a}(0.19)$ \\
\hline $\mathrm{CP}$ & $15.7 \mathrm{~b}(0.83)$ & 1.73 a (0.07) & $3.60 \mathrm{a}(0.26)$ & $1.40 \mathrm{a}(0.06)$ & $1.71 \mathrm{~b}(0.10)$ \\
\hline NF & $7.9 \mathrm{c}(0.43)$ & $1.40 \mathrm{~b}(0.06)$ & $2.42 \mathrm{~b}(0.19)$ & $1.10 \mathrm{~b}(0.05)$ & $1.49 \mathrm{~b}(0.10)$ \\
\hline
\end{tabular}

${ }^{2}$ For crown and root dry weights, $\mathrm{n}=90$; sE are reported in parentheses.

${ }^{\mathrm{y}} \mathrm{MBCP}=$ methyl bromide : chloropicrin; $\mathrm{CP}=$ chloropicrin; $\mathrm{NF}=$ nonfumigated (control); see text for rates.

${ }^{x}$ Pooled means for both cultivars, $\mathrm{n}=12$; SE are reported in parentheses.

wean separation within columns by Tukey's Studentized range test, $P \leq 0.05$.

(Table 1). Therefore, for each fumigation treatment, runner production data were pooled for the two cultivars and the two spacings for determination of mean runner production per mother plant.

For $\mathrm{CP}$ and NF, runner production per mother plant was reduced $15 \%$ and $57 \%$, respectively, compared to MBCP (Table 2). For 'Selva' plants, there were no significant differences in crown dry weights or root dry weights between MBCP and CP. However, for 'Chandler', root dry weight for CP was reduced relative to that of MBCP. For 'Selva', runner crown and root dry weights for NF were lower than for the other two treatments, $\mathrm{kg} \cdot \mathrm{ha}^{-1}$ resulted in significant increases in runner yield and runner size compared to NF, although yield and size were reduced compared to fumigation with a mixture of 67 methyl bromide : 33 chloropicrin (by weight, $392 \mathrm{~kg} \cdot \mathrm{ha}^{-1}$ ). For NF, the marked reduction in runner production and size demonstrates the importance of preplant soil fumigation for enhancing runner production and runner quality in strawberry nurseries, even on new nursery ground.

Additional work is needed to evaluate the effect of soil fumigation with various rates of $\mathrm{CP}$, applied in spring and fall, on strawberry runner production.

\section{Literature Cited}

Himelrick, D.G. and W.A. Dozier. 1991. Soil fumigation and soil solarization in strawberry production. Adv. Strawberry Prod. 10:12-28.

Processing Strawberry Advisory Board of California. 1993. Annual report. Processing Strawberry Advisory Board of California, Watsonville.

Voth, V. and R.S. Bringhurst. 1990. Culture and physiological manipulation of California strawberries. HortScience 25:889-892.

Watson, R.T., D.L. Albritton, S.O. Anderson, and S.E. Bapty. 1992. Methyl bromide: Its atmospheric science, technology, and economics. Montreal Protocol Assessment Summary, United Nations Environment Program, Nairobi, Kenya.

Welch, N. 1989. Strawberry production in California. Univ. of California Coop. Ext. Lflt. 2959.

Wilhelm, S. 1961. Diseases of strawberry. A guide for the commercial grower. Calif. Agr. Expt. Sta. Circ. 494

Wilhelm, S. and A.O. Paulus. 1980. How soil fumigation benefits the California strawberry industry. Plant Dis. 64:264-270.

Wilhelm, S., R.C. Storkan, and J.M. Wilhelm. 1974. Preplant soil fumigation with methyl bromidechloropicrin mixtures for control of soil-borne diseases of strawberries-A summary of fifteen years of development. Agr. Environ. 1:227236.

Yuen, G.Y., M.N. Schroth, A.R. Weinhold, and J.G. Hancock. 1991. Effects of soil fumigation with methyl bromide and chloropicrin on root health and yield in strawberry. Plant Dis. 75:416-420. 